\title{
Morphometric patterns and preferential uses of Capsicum peppers in the State of Roraima, Brazilian Amazonia
}

\author{
Reinaldo I Barbosa ${ }^{1}$; Moisés Mourão Júnior ${ }^{2}$; Francisco Joaci de F Luz ${ }^{3}$ \\ ${ }^{1}$ INPA-Núcleo de Pesquisas de Roraima, R. Coronel Pinto 315, Centro, 69301-150 Boa Vista-RR; ${ }^{2}$ Embrapa Amazônia Oriental, C. \\ Postal 48, 66095-100 Belém-PA; ${ }^{3}$ Embrapa Roraima, C. Postal 133,69301-970 Boa Vista-RR; reinaldo@inpa.gov.br; mmourao@cpatu. \\ embrapa.br; chefia@cpafrr.embrapa.br
}

\begin{abstract}
Our objective was to study distinctions in the morphology of the pepper fruits (Capsicum spp., Solanaceae) used by indigenous (living in traditional villages) and non-indigenous groups (originated from migration and colonization, with or without miscegenation, living on non-indigenous lands) in the State of Roraima, Northern Brazilian Amazonia. In this sense, we used a database with 182 subsamples of Capsicum spp. Accessions were collected at 39 sites (14 indigenous and 25 non-indigenous), which were characterized additionally in relation to the predominant phytophysiognomy (savanna or forest) and home zone (rural or urban). We found morphological differences in pepper fruits related to both phytophysiognomy and home zone of the collecting site, but not to ethnical origin. We believe those differences are more related to the inherent crop practices, which suffer strong environmental influence, than to user preference. Both indigenous and non-indigenous groups preferred morphotypes from $C$. chinense and $C$. frutescens, which have small and highly pungent fruits. Nevertheless, fruit color was not important. These morphotypes are used by both indigenous and non-indigenous users for preparing sauce and jiquitaia (pepper powder). We suggested 'cultural adherence' as the reason for the common preferred use of peppers by both ethnical groups analyzed in Roraima.
\end{abstract}

Keywords: Capsicum chinense, Capsicum frutescens, agrobiodiversity, ethnic botanic, pungency, descriptors.

\section{RESUMO}

Padrões morfométricos e usos preferenciais de pimentas Capsicum spp. em Roraima, Amazônia brasileira

O objetivo deste estudo foi verificar distinções no padrão morfológico de frutos de pimentas do gênero Capsicum spp. (Solanaceae) utilizados por grupos tradicionais indígenas (vivendo em aldeias) e não-indígenas (derivado da migração/colonização, contendo ou não miscigenação, situados fora de áreas indígenas), em Roraima, norte da Amazônia brasileira. Para tanto foi utilizado um banco de dados com 182 subamostras de Capsicum spp. coletadas em 39 localidades daquele estado (14 indígenas e 25 não-indígenas). As localidades foram caracterizadas também por tipos fitofisionômicos predominantes (savana ou floresta) e por zona domiciliar do usuário (rural ou urbana). Os resultados indicaram haver diferenças morfológicas nos frutos de pimenta relacionadas tanto a fitofisionomia, quanto a zona domiciliar da área de coleta, mas não a origem étnica do grupo. Isto indica que as diferenças estão relacionadas mais a fatores inerentes aos tratos culturais, fortemente influenciados pelo ambiente, que à preferência do usuário. Os morfotipos com frutos de menor peso e alta pungêngia das espécies $C$. chinense e $C$. frutescens, independente da cor, foram os preferidos dos usuários indígenas e não-indígenas para produção de molhos e jiquitaia (pó de pimenta). A 'aderência cultural' é sugerida para explicar o uso preferencial comum de pimentas entre os agrupamentos étnicos analisados em Roraima.

Palavras-chave: Capsicum chinense, Capsicum frutescens, agrobiodiversidade, etnobotânica, pungência, descritores.

\section{(Recebido para publicação em 11 de agosto de 2009; aceito em 30 de agosto de 2010)}

\section{(Received on August 11, 2009; accepted on August 30, 2010)}

$\mathrm{T}$ he peppers from the genus Capsicum spp. (Solanaceae) are native from the Americas. Archaeological records indicate that Capsicum species were already consumed at least 8,600-5,600 $\mathrm{BC}$ in the Andean regions of Peru and 6,500-5,500 BC in Mexico (Nuez et al., 1998), which makes Capsicum one of the first domesticated species used for food in the Americas (Pickersgill, 1969). The earlier descriptions of the use and shape of Capsicum fruits were made by the chroniclers of the Christopher Columbus' first voyages to the Americas (Pietro Martire d'Anghiera, in 1493, and Diego Alvarez Chanca, in 1494).
Both reported the existence of a spicy fruit that was used as condiment by the inhabitants in La Española, now the Dominican Republic and Haiti (Lembeck, 1987). In Brazil, the first reports are attributed to Hans Staden, a German shipwrecked who settled along the coast with the Tupinambá indigenous group, between 1,547-1,555 (Reifschneider, 2000).

Due to its broad use in cookery and medicine, Capsicum species were very rapidly disseminated to other parts of the world (Mateos et al., 2003). From the sixteenth century downwards, Spanish and Portuguese started bringing Capsicum to their colonies in Africa and Asia through its commercial corridors (Andrews, 1993). The exchange and dissemination of genetic material suggests that, at first, the settlers carried the standard fruit selection (color, pungency, shape and size) and propagated the use as they found in America to spread the genus. Routes covering different human groups and distinct Capsicum dispersal centers in the Americas were used for the transit and exchange of food resources (cultural diffusion) much faster and more intensively than in the pre-Columbian period (Heiser, 1965). 
However, this does not mean that the standards were maintained over time, also because Capsicum species exhibit a wide variety of shapes, colors and sizes (Walsh \& Hoot, 2001).

Preference patterns indicate cultural traits (food, medicinal, ritual, etc.), which are intrinsic to different population groups. These preferences provide information on market acceptance and the processing industry in distinct regions and groups. Preferences appear as consequence of the cultural independence that encourages ideas and practices, which, in their turn, coupled with local environmental specificities, benefit certain types of plants (Portis et al., 2006). Studies that support the advance of knowledge on in situ and ex situ strategies to preserve genetic resources provide a basis for the development of regional agricultural programs and land use plans (Tewksbury et al., 1999; Guzman et al., 2005).

This study aimed to determine morphometric distinctions between the patterns of Capsicum spp. fruits used by traditional indigenous populations and non-indigenous groups (migrant/ settlers). We took the State of Roraima, situated on the Northern edge of the Brazilian Amazonia as case study. We also wanted to check the existence of association between preferred uses and biometric standards, color and pungency of fruits for each of the Capsicum species and morphotypes investigated.

\section{MATERIAL AND METHODS}

Database - We used the database (DB) of Capsicum pepper species and cultivars consumed in the State of Roraima (Barbosa et al., 2002, Barbosa et al., 2006) to search for distinctions in the pattern of fruit choices and uses between indigenous (IN) and nonindigenous (NI) groups. The DB was generated between 2000 and 2001 and contains information on 182 accessions (subsamples), collected at 39 sites in Roraima, 14 classified as indigenous and 25 as non-indigenous. In both cases, we added information on phytofisiognomy (savanna or forest) and home area (urban or rural). In the current study, we took the $163(89.6 \%)$ subsamples that had information on all fields needed for the assembly of the matrix analysis. The variables selected for analysis were: (1) species (taxonomic classification and domestication status): (i) DOME (domesticated, 4 species), (ii) SEMI (semidomesticated, 1) and (iii) WILD (wild, 1); (2) morphotype: the 163 accessions were clustered into 86 morphotypes, regardless of the collecting site and the common name provided by the user; (3) predominant color: (Y) yellow (including shades of cream and orange) and $(\mathrm{R})$ red (including variations); (4) pungency: structured in four classes based on the SHU scale (Scoville Heat Unit) as (L) low $(<25,000$ SHU), (M) medium $(25,000-75,000$ SHU), (H) high $(75,000-150,000$ SHU) and (VH) very high $(>150,000$ SHU); (5) fruit shape: modified from IPGRI (1995), (i) elongated, (ii) block, (iii) belly, (iv) cone, (v) oval, (vi) round and (vii) variable; (6) preferential use: based on the information received upon collecting the material, as (i) sauce (either creamy or liquid), (ii) sauce and jiquitaia (pepper powder), (iii) sauce and salad (fruits consumed in natura), (iv) ornamental (not used as food), (v) salad and steamed (used for cooking) and (vi) other uses (rare, for example, in rites); (7) fruit fresh weight, in grams (g), based on the average of ten mature fruits randomly collected or given by the user, classified into (IPGRI, 1995): (i) $<4.5 \mathrm{~g}$, (ii) $4.6-9.0 \mathrm{~g}$, (iii) $9.1-13.5 \mathrm{~g}$, (iv) 13.6 - 18.0 g (v) 18.1 - 22.5 g, (vi) 22.6 - 27.0 $\mathrm{g}$, (vii) 27.1 - $31.5 \mathrm{~g}$ and (viii) $>31.6 \mathrm{~g}$; (8) fruit width and length, in centimeters (cm), following the IPGRI guidelines (1995). Morphological markers 7 and 8 were used for statistical analysis. For the morphometric characterization, we used 10 fruits per morphotype collected at random or given by the user.

Data Analysis - The DB was regrouped according to color, pungency, shape, preferential use and weight of fruits, generating a code for each user (sampling unit). We then carried out a descriptive analysis based on ethnical groups (IN and NI), phytophysiognomy (forest or savanna) and home zone (rural or urban). We used the cluster dissimilarity analysis (D2 - Mahalanobis) with the subsequent application of a probabilistic criterion to understand the existence of homogeneous groups (Johnson \& Wichern, 1998). This multivariate technique takes into account the distance between groups formed by a set of sub-samples (multivariate samples), based on the correlations between the morphological markers (variables) that were considered for analysis. In this study we used fruit width $(\mathrm{cm})$, length $(\mathrm{cm})$, weight $(\mathrm{g})$ and shape index (average length:width = $\mathrm{L}: \mathrm{W})$. The test of Scheffé was adopted to provide a statistical distinction among the media for these markers (Manly, 1994). In addition to the grouping, we carried out a factorial sorting (Factor Analysis) in order to understand how each component (axis) influenced the variation among groups and which morphological characteristics have stronger discriminating power. Finally, all morphometric characteristics were grouped by species, morphotype, color, shape, pungency and use of fruits to allow studying the preferential distinctions between indigenous and non-indigenous groups.

\section{RESULTS AND DISCUSSION}

Species biometric standards - Over $70 \%$ of the analyzed subsamples were Capsicum chinense Jacq. (Table 1). Bell pepper (C. annuum L. var. annuиm) fruits had the highest average weight and dimensions (length and width), while C. annuum L. var. glabriusculum (semi-domesticated) and C. frutescens L. had the lowest values. C. baccatum var. pendulum (Willd.) Eshbaugh and $C$. annuum L. biometric standards for fruit weight and length differed significantly from the others at the $5 \%$ probability (Scheffé test). These results agreed with the taxonomic characteristics described for the main Capsicum cultivated species (Pickersgill \& Heiser, 1969) and therefore are consonant with the expected morphometric separation (Smith \& Heiser, 1957). The statistical differences in the morphometric patterns herein identified are merely expressing the history of the Capsicum domestication process, which was guided by the characteristics that were privileged by a given human group 
Table 1. Biometric quantification of fruits of different species and varieties of Capsicum (Solanaceae) peppers derived from the database of the State of Roraima, Brazil (quantificação biométrica dos frutos das diferentes espécies e variedades de pimentas Capsicum (Solanaceae) provenientes do banco de dados do estado de Roraima). Boa Vista, INPA, 2007.

\begin{tabular}{lrrcl}
\hline \multicolumn{1}{c}{ Specie $^{1}$} & $\mathbf{N}^{2}$ & $\begin{array}{c}\text { Weight } \\
(\mathbf{g})\end{array}$ & $\begin{array}{c}\text { Length } \\
(\mathbf{c m})\end{array}$ & $\begin{array}{c}\text { Width } \\
(\mathbf{c m})\end{array}$ \\
\hline C. annuum (except bell pepper) & 4 & $11.10 \mathrm{a}$ & $5.31 \mathrm{a}$ & $2.44 \mathrm{a}$ \\
C. annuum var. annuum (bell pepper) & 6 & $30.10 \mathrm{~b}$ & $8.17 \mathrm{~b}$ & $4.42 \mathrm{~b}$ \\
C. annuum var. glabriusculum & 9 & $0.34 \mathrm{c}$ & $1.11 \mathrm{c}$ & $0.71 \mathrm{c}$ \\
C. baccatum var. pendulum & 9 & $12.21 \mathrm{a}$ & $5.11 \mathrm{a}$ & $3.60 \mathrm{~d}$ \\
C. chinense & 117 & $3.47 \mathrm{~d}$ & $3.62 \mathrm{~d}$ & $1.63 \mathrm{e}$ \\
C. frutescens & 18 & $0.30 \mathrm{e}$ & $1.70 \mathrm{e}$ & $0.48 \mathrm{f}$ \\
\hline
\end{tabular}

${ }^{1}$ Values preceded of same letter in the vertical do not differ significantly using level of $5 \%$ according to the test of Scheffé (valores precedidos de mesma letra na vertical não diferem significativamente no nível de 5\% segundo o teste de Scheffé).

${ }^{2}$ Number of accessions (subsamples) analyzed.

Table 2. Average and standard deviation of the morphologic markers, ordered according to the test of Scheffé (média e desvio padrão dos marcadores morfológicos, ordenados segundo o teste de Scheffé). Boa Vista, INPA, 2007.

\begin{tabular}{cllll}
\hline \multirow{2}{*}{ Groups } & \multicolumn{4}{c}{ Morphological markers $^{1}$} \\
\cline { 2 - 5 } & Width $(\mathbf{c m})$ & \multicolumn{1}{c}{ Length $(\mathbf{c m})$} & Weight $(\mathbf{g}) \mathbf{L}: \mathbf{W}$ \\
\hline $\mathrm{G}_{1}$ & $2.17 \pm 0.29 \mathrm{ab}$ & $3.33 \pm 0.76 \mathrm{ab}$ & $3.90 \pm 1.30 \mathrm{ab}$ & $1.55 \pm 0.40 \mathrm{~b}$ \\
$\mathrm{G}_{2}$ & $1.32 \pm 0.96 \mathrm{~b}$ & $3.03 \pm 2.04 \mathrm{~b}$ & $3.38 \pm 6.32 \mathrm{~b}$ & $2.48 \pm 1.44 \mathrm{a}$ \\
$\mathrm{G}_{3}$ & $1.63 \pm 1.12 \mathrm{~b}$ & $3.45 \pm 2.33 \mathrm{ab}$ & $3.87 \pm 5.43 \mathrm{~b}$ & $2.43 \pm 1.47 \mathrm{a}$ \\
$\mathrm{G}_{4}$ & $2.09 \pm 1.46 \mathrm{a}$ & $4.33 \pm 3.16 \mathrm{a}$ & $7.60 \pm 9.48 \mathrm{a}$ & $2.39 \pm 1.45 \mathrm{a}$ \\
\hline Total & $1.68 \pm 1.19$ & $3.56 \pm 2.49$ & $4.60 \pm 6.80$ & $2.42 \pm 1.44$ \\
\hline
\end{tabular}

${ }^{1}$ Values preceded of same letter in the vertical do not differ significantly using level of $1 \%$ according to the test of Scheffé (valores precedidos de mesma letra na vertical não diferem significativamente no nível de 1\% segundo o teste de Scheffé).

and seem to be independent of having taken place at centers of dispersal or elsewhere.

Grouping users - The application of the distance of Mahalanobis for developing a dendrogram based on the association between fruit morphological characteristics and ethnic group (indigenous and non-indigenous), phytophysiognomy (forest or savanna) and home zone (rural or urban) generated four distinct user groups (Figure 1).

The first group (G1) includes three subsamples collected with indigenous people who live in the forest, in rural areas. Compared to the others, this is the most homogeneous and isolated group. The indigenous group who cultivate these subsamples, although in contact with other people, preserved the preferential morphometric characteristics of the fruits they traditionally grow. Some studies report the use of $C$. frutescens sites.

The third group (G3) comprises 92 subsamples cultivated by nonindigenous from both rural and urban areas, living in the savanna. This group forms what Winklerprins (2002) called the 'rural-urban continuum'. The city serves as a reference of housing, an extra income source and a place with better health and education opportunities. For this group, Berg \& Silva (1988) had already detected Capsicum morphotypes in homes and markets in Boa Vista, the State capital, with the varied uses. Nevertheless, these authors did not care about species or how they were employed in cookery or for medical purposes.

The fourth group (G4) gathered 36 subsamples cultivated by (a) nonindigenous living in small towns and cities (urban) throughout the Southern section of road BR-174 (forest), in general, migrants from the NorthNortheast of the country; and (b) indigenous living in urban areas of the savanna. The last form is a movement "indigenous village-city" that confers to indigenous people broader access to paid work and health facilities. This is the most conflicting group of subsamples, which apparently demonstrates that Capscium species and cultivars have a wider transit than what is represented by Roraima's geographic borders. These genetic resources exchange and dissemination movements are broad and mix cultural traits from different Brazilian regions in Roraima (more strongly in the post-1970).

The short distance between G2, G3 and G4, the best sampled groups, with 160 subsamples (Figure 1), can indicate that these three groups form a more compact cluster, far apart from G1 (indigenous villages located in forest regions). The latter has a smaller number of observations (3) and lays far apart from the other groups, representing geographic areas which are more isolated from urban centers. A larger number of samples from these sites should produce more refined information about the use of Capsicum by these ethnic groups, regardless of the contacts between them and other human groups which may have introduced 
Table 3. Eigenvalues and eigenvectors of the morphological markers evidenced by factor analysis; values in boldface: $|\lambda| \geq 0.60$ (autovalores e autovetores dos marcadores morfológicos evidenciados pela análise fatorial; valores em negrito: $|\lambda| \geq 0,60)$. Boa Vista, INPA, 2007.

\begin{tabular}{lcc}
\hline Eigenvectors from morphological markers & PCA I & PCA II \\
\hline Width (W) & -0.89 & -0.40 \\
Length (L) & -0.81 & 0.54 \\
Weight & -0.94 & -0.18 \\
LW: Ratio & -0.08 & 0.98 \\
\hline Eigenvalue & 2.33 & 1.44 \\
\% of variance explained & 58.37 & 35.99 \\
Cumulative \% explained & 58.37 & 94.36 \\
\hline
\end{tabular}

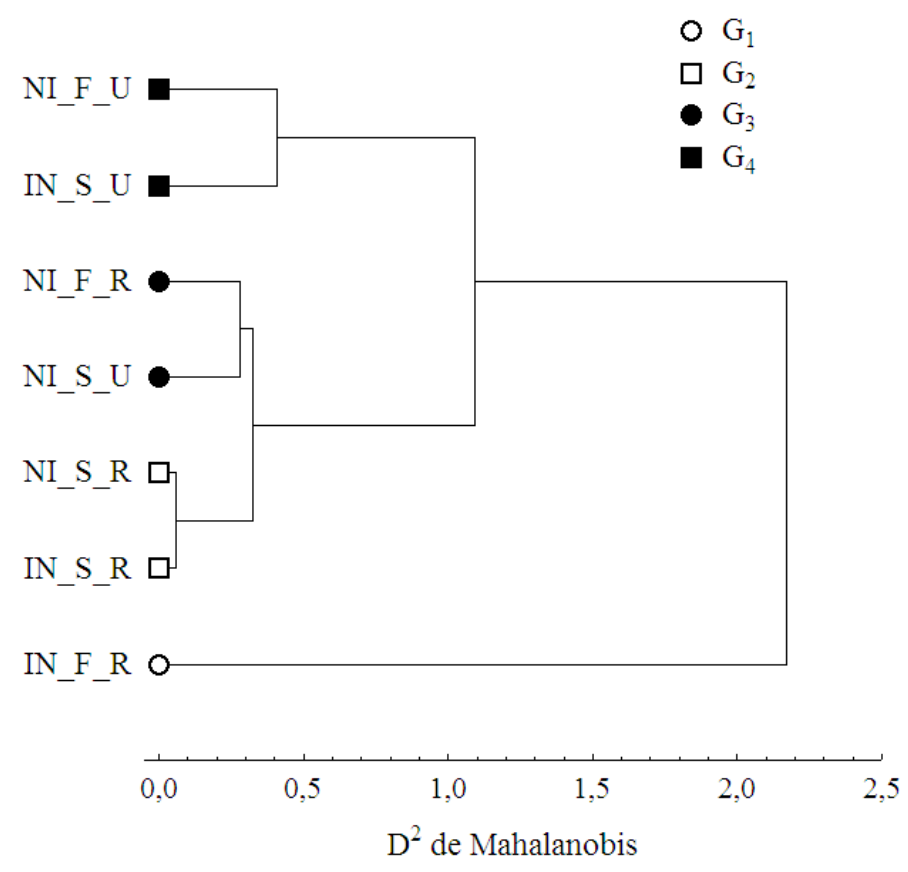

Figure 1. Dendrogram of dissimilarity among consumer groups of peppers Capsicum spp. ( $\mathrm{NI}=$ non-indigenous and $\mathrm{IN}=$ indigenous; $\mathrm{F}=$ forest and $\mathrm{S}=$ savanna; $\mathrm{U}=$ urban and $\mathrm{R}=$ rural) (dendrograma de dissimilaridade entre os grupos consumidores de pimentas Capsicum spp. ( $\mathrm{NI}=$ não-indígena e $\mathrm{IN}=$ indígenas; $\mathrm{F}=$ floresta e $\mathrm{S}=$ savana, $\mathrm{U}=$ urbano e $\mathrm{R}=$ rural)). Boa Vista, INPA, 2007.

recent habits and usages.

Morphological markers as determinants of ethnic groups - The clustering of the Capsicum samples allowed for the calculation of the mean and standard deviations for the morphological markers in each class (Table 2). The largest absolute distances between $\mathrm{G} 1$ and the other groups were recorded for fruit length:width ratio $(\mathrm{L}: \mathrm{W})$, confirmed as statistically significant by Scheffe's test. The PCA I ( $58 \%$ of the total variability) revealed significant differences between the eigenvectors for fruit length, width and and determine their constitution. Sudré et al. (2006) using 13 multicategorical variables described by IPGRI (1995), not involving fruit weight and size, identified differences among subsamples of the evaluated species. The two PCA axes explained almost all the variability observed among the Capsicum accessions we used, suggesting that morphometric markers are effective for identifying preference distinctions from Caspsicum consumers.

Grouping of species/ morphotypes by preferred use - The most representative Capsicum spp. morphotype in the ethnic groups, both indigenous and non-indigenous, was Murupi (C. chinensis). Murupi fruits are elongated, range from red to yellow, have high pungency and weigh less than 4.5 $\mathrm{g}$ each. Non-indigenous preferably use it as sauce, while indigenous associate sauce with jiquitaia (pepper powder). Morphotypes with fruits of smallest weight, length and width were those identified as highly pungent, therefore used to prepare sauce and jiquitaia (pepper powder). This was a suggestion made by Cochran (1940), indicating that genotypes with smaller fruits carry also high pungency heritability factors. These are characteristics of $C$. chinense and C. frutescens, which are used by both indigenous and nonindigenous. The two species have wide cultural diffusion in both ethnic groups and are geographically present in the commercial routes since the first contacts (Smith \& Heiser, 1957; Heiser, 1969).

Fruit size and pungency are always among the preferred characteristics in the surveys of Capsicum use in Amazonia. Fonseca et al. (2008) detected only three subsamples of $C$. chinense with low pungency in a total of 38 morphologically characterized accessions collected in the upper Rio Negro (Amazonas). In general, larger and heavier fruits have low pungency and are used in Roraima for cooking as sautéed, in this case, scented chili $(C$. chinense); and for salads, especially bell peppers (C. апnuит var. annuиm) and Brown's pepper (C. baccatum var. pendulum) (Nascimento Filho et al., 2007). Consumers' choice in relation 


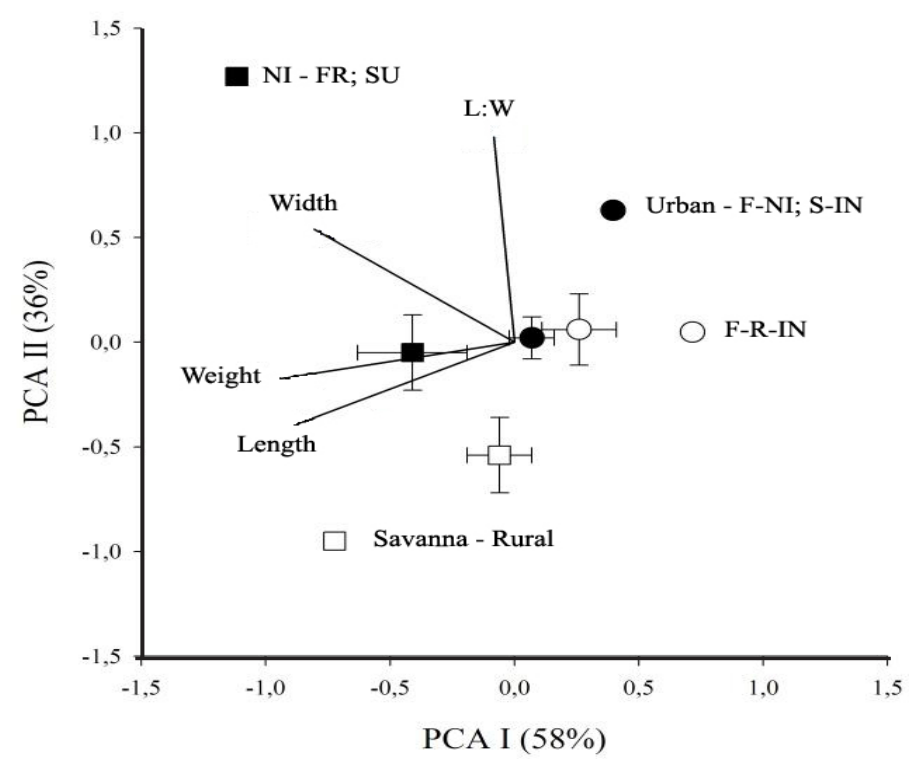

Figure 2. Average and standard error from scores obtained by factor analysis, where $\mathrm{F}=$ forest and $\mathrm{S}=$ savanna; $\mathrm{IN}=$ indigenous and $\mathrm{NI}=$ non-indigenous; $\mathrm{R}=$ rural and $\mathrm{U}=$ urban (valores médios e erro padrão dos escores obtidos na análise fatorial, onde $\mathrm{F}=$ floresta e $\mathrm{S}=$ savana; $\mathrm{IN}=$ indígena e $\mathrm{NI}=$ não indígena; $\mathrm{R}=$ rural e $\mathrm{U}=$ urbano). Boa Vista, INPA, 2007.

to large fruits lies much more on fruit consistency and morphological dimensions than on pungency (Olarewaju \& Aliyu, 1994).

We concluded that it is possible to distinguish between different groups of users (IN and NI) of Capsicum peppers in Roraima using morphometric markers, phytophysiognomy and home zone. The distinction can arise from different crop practices or morphotype adaptation to the environment where it is grown. However, the distinction derived from morphometric markers and the subsequent formation of four classes of users did not provide clear patterns of culinary use by species, morphotypes or fruit color, shape and pungency between the two ethnic groups (IN and NI). Overall, both groups use preferably morphotypes with small, low weight and high pungent fruits (C. chinense and C. frutescens) for preparing sauces and jiquitaia (pepper powder), and large, high weight and low pungent fruits ( $C$. annuиm var. annuиm, C. baccatum var. pendulum and some cultivars of $C$. chinense) for salads and cooking. This can be explained by the historical cultural links between these two major ethnic groups in Roraima, which results in a two-way exchange of habit and usages and leads to a set of common rules for the preferential choice of Capsicum fruits based mainly on the needs for home use.

\section{ACKNOWLEDGEMENTS}

The government of the State of Roraima sponsored the construction of the database through the $3^{\text {rd }}$ Addendum of Technical and Scientific Cooperation Agreement (027/99) - INPA/GERR.

\section{REFERENCES}

ALIYU L; OLAREWAJU JD. 1994. Variation in morphological and agronomic characters in sweet pepper (Capsicum annuиm L.). Capsicum and Eggplant Newsletter 13: 62-63.

ANDREWS J. 1993. Diffusion of Mesoamerican food complex to Southeastern Europe. Geographical Review 83: 194-204.

BARBOSARI; LUZ FJF; NASCIMENTO FILHO HR; MADURO CB. 2002. Pimentas do gênero Capsicum cultivadas em Roraima, Amazônia brasileira. I. Espécies domesticadas. Acta Amazônica 32: 177-192.

BARBOSA RI; LUZ FJF; NACIMENTO FILHO
HR; MADURO CB. 2006. Pimentas de Roraima (Catálogo de Referência). Manaus: EDUA \& Editora INPA (Série Biblioteca Científica da Amazônia). 93p.

BARBOSA RI; CAMPOS C; PINTO F; FEARNSIDE PM. 2007. The "Lavrados" of Roraima: Biodiversity and Conservation of Brazil's Amazonian Savannas. Functional Ecosystems and Communities 1: 29-41.

BERG EMVD; SILVA MHL. 1988. Contribuição ao conhecimento da flora medicinal de Roraima. Acta Amazonica 18: 23-35.

COSTA FR; PEREIRA TNS; VITÓRIA AP; CAMPOS KP; RODRIGUES R; SILVA DJH; PEREIRA MG. 2006. Genetic diversity among Capsicum accessions using RAPD markers. Crop Breeding and Applied Biotechnology 6:18-23.

COCHRAN HL. 1940. Characters for the classification and identification of cultivars of Capsicum. Bulletin of the Torrey Botanical Club 67: 710-717.

FONSECARM; LOPES R; BARROS WS; LOPES MTG; FERREIRA FM. 2008. Morphologic characterization and genetic diversity of Capsicum chinense Jacq. accessions along the upper Rio Negro - Amazonas. Crop Breeding and Applied Biotechnology 8: 187-194.

GUZMÁN FA; AYALAH; AZURDIAC; DUQUE MC; VICENTE MC. 2005. AFLP Assessment of genetic diversity of Capsicum genetic resources in Guatemala: home gardens as an option for conservation. Crop Science 45: 363-370.

HEISER CB. 1965. Cultivated plants and cultural diffusion in nuclear America. American Anthropologist (New Series) 67: 930-949.

HEISER CB. 1969. Systematics and the origin of cultivated plants. Taxon 18: 36-45.

HEISER CB; PICKERSGILL B. 1969. Names for the cultivated Capsicum species (Solanaceae). Taxon 18: 277-283.

ISA-Instituto Socioambiental. 2008. Nota técnica sobre áreas protegidas em Roraima. São Paulo: Instituto Socioambiental. Disponível em http://www.socioambiental.org/inst/esp/ raposa/?q=node/78. Acessado em 01 de Março de 2008.

IPGRI 1995. Descriptors for Capsicum (Capsium spp.). Rome: International Plant Genetic Resources Institute (IPGRI). 49p.

JOHNSON RA; WICHERN DW. 1998. Applied multivariate statistical analysis ( $4^{\text {th }}$ Edition). New Jersey: Prentice Hall. 815p.

LEMBECK F. 1987. Columbus, capsicum and capsaicin - past, present and future. Acta Physiologica Hungarica 69: 265-273.

MANLY BFJ. 1994. Multivariate Statistical Methods: A Primer (2 ${ }^{\text {nd }}$ Edition). Dunedin: Chapman \& Hall. 215p.

MATEOS RM; LEON AM; SANDALIO, LM; GÓMEZ; M; DEL RIO; LA; PALMAJM. 2003. Peroxisomes from pepper fruits (Capsicum anпиит L.): purification, characterization and antioxidant activity. Journal of Plant Physiology 160: 1507-1516.

MILLIKEN W; ALBERT B. 1997. The use of medicinal plants by the Yanomami Indians of Brazil, Part II. Economic Botany 51: 264-278. 
MILLIKEN W; MILLER RP; POLLARD SR; WANDELLI EV. 1992. Ethnobotany of the Waimiri Atroari Indians of Brazil. Kew: Royal Botanic Gardens. 146p.

NASCIMENTO FILHO HR; BARBOSA RI; LUZ FJF. 2007. Pimentas do gênero Capsicum cultivadas em Roraima, Amazônia brasileira. II. Hábitos e formas de uso. Acta Amazonica 37: 561-568.

NUEZ F; DÍEZ MJ; RUIZ JJ; FERNÁNDEZ DE CORDOVA P; COSTA J; CATALÁ MS; GONZÁLEZ JA; RODRÍGUEZ A. 1998. Catálogo de semilias de pimiento. Madrid: Ministerio de Agricultura, Pesca y Alimentación / Instituto Nacional de Investigación y Tecnologia Agraria y Alimentaria. 108p.

PICKERSGILL B. 1969. The archaeological record of chili peppers (Capsicum spp.) and the sequence of plant domestication in Peru. American Antiquity 34: 54-61.
PORTIS E; NERVO G; CAVALLANTI F; BARCHI L; LANTERI S. 2006. Multivariate analysis of genetic relationships between Italian Pepper landraces. Crop Science 46: 2517-2525.

REIFSCHNEIDER FJB (org.). 2000. Capsicum: pimentas e pimentões no Brasil. Brasília: EMBRAPA-Hortaliças. 113p.

SCHOMBURGK RH. 1840. Journey from Fort San Joaquim, on the Rio Branco, to Roraima, and thence by the Rivers Parima and Merewari to Esmeralda, on the Orinoco, in 1838-9. Journal of Royal Geographical Society 10: 191-247.

SMITH PG; HEISER CB. 1957. Taxonomy of Capsicum sinense Jacq. and the geographic distribution of the cultivated Capsicum species. Bulletin of the Torrey Botanical Club 84: 413-420.

SUDRÉ CP; CRUZ CD; RODRIGUES R; RIVA EM; AMARAL JUNIOR AT; SILVA
DJH; PEREIRA TNS. 2006. Variáveis multicategóricas na determinação da divergência genética entre acessos de pimenta e pimentão. Horticultura Brasileira 24: 88-93.

TEWKSBURY J; NABHAN GP; NORMAN D; SUZÁN H; TUXILL J; DONOVAN J. 1999. Situ conservation of wild chiles and their biotic associates. Conservation Biology 13: 98-107.

WALSH BM; HOOT SB. 2001. Phylogenetic relationships of Capsicum (Solanaceae) using DNA sequences from two noncoding regions: the chloroplast atpb-rbcl spacer region and nuclear waxy introns. International Journal of Plant Science 162: 1409-1418.

WINKLERPRINS AMGA. 2002. House-lot gardens in Santarém, Pará, Brazil: Linking rural with urban. Urban Ecosystems 6: 4365 . 